\title{
CS-31 -Diagnóstico de la ISO 14001:2015 en la Empresa Purificadora de Agua BERMAR S.A de C.V.
}

\author{
Diagnosis of ISO 14001: 2015 in The Purification Company of Water \\ BERMAR S.A de C.V.
}

\author{
Nancy Tass *, Patsy Ortiz, Luis Zarate \\ División Académica de Educación y Artes, Universidad Juárez Autónoma de Tabasco, México.
}

*Autora a quien se dirige la correspondencia: nancy.tass84@gmail.com

\section{Resumen}

$\mathrm{E}$ 1 Sistema de Gestión Ambiental ISO 14001 tiene como objetivo servir de soporte a la prevención y manejo de la contaminación ambiental, en equilibrio con las necesidades socioeconómicas de los diferentes sectores de la sociedad. En la empresa Purificadora de Agua BERMAR S.A. de C.V. ubicada en el Municipio de Balancán, Tabasco, se realizó un diagnóstico por medio de diversas herramientas para la detección de oportunidades de mejora siguiendo los lineamientos de la norma ISO 14001:2015; con la finalidad de analizar el status actual de la empresa, así como los beneficios de aplicar la norma. La información recabada se centra en el análisis de la situación actual de los requisitos legales, aspectos, impactos y manejo ambiental de la organización, considerada como la Fase 1, del proyecto de investigación Gestión Integral: Calidad y Productividad en la Empresa Purificadora de Agua BERMAR S.A. de C.V. Se espera que los resultados de esta investigación motiven a la organización en la búsqueda de la certificación de sus procesos en gestión ambiental y que le permitan lograr mayor competitividad.

Palabras claves: ISO 14001, identificación, oportunidad de mejora, empresa, impacto ambiental

\section{Abstract}

$\mathrm{T}$ he Environmental Management System ISO 14001 aims to support the prevention and management of environmental pollution, in balance with the socioeconomic needs of different sectors of society. In the company Purificadora de Agua BERMAR S.A. of C.V. located in the Municipality of Balancán, Tabasco, a diagnosis was made through various tools to detect opportunities for improvement following the guidelines of ISO 14001: 2015; with the purpose of analyzing the current status of the company, as well as the benefits of applying the standard. The information gathered focuses on the analysis of the current situation of legal requirements, aspects, impacts and environmental management of the organization, considered as Phase 1, of the research project Integral Management: Quality and Productivity in the Water Purifying Company BERMAR SA of C.V. It is hoped that the results of this research motivate the organization in the search for certification of its processes in environmental management and that allow it to achieve greater competitiveness.

Key words: ISO 14001, identification, opportunity for improvement, company, environmental impact 